Saeculum Christianum

vol. XXIV (2017)

pp. $186-199$

\author{
ADA LEWANDOWSKA
}

Faculty of Historical and Social Sciences

Cardinal Stefan Wyszyński University in Warsaw

\title{
EXTRAORDINARY EVENTS, DISASTERS AND MARCHING ARMIES IN GREATER POLAND IN THE 17TH AND 18TH CENTURIES AND THEIR IMPACT ON THE LIFE OF NUNS IN THE BENEDICTINE MONASTERY AS REFLECTED IN THE MONASTIC CHRONICLE1
}

The unfavourable situation in which monasteries of the Commonwealth of Poland and Lithuania found themselves in the 16th century triggered a collapse of religious and monastic life. One of the symptoms of this decline was that monks and nuns were abandoning their cloistered life and became Protestants. This crisis was the reason for the collapse of many monasteries, including those belonging to the Benedictines. Only three congregations of nuns of the Order of St. Benedict survived the aftermath of the Reformation in Poland: in Staniątki, Toruń and Chełmno ${ }^{2}$. The last monastery was unique; as there were fears that the municipality would take over the property after the death of the last Benedictine nun in 1578, it was home to two sisters of St. Barnardine, one Poor Clare and six frightened novices $^{3}$. That very year they were joined by Magdalena Mortęska ${ }^{4}$, later an abbess of Chełmno, who reformed the congregation on the basis of the Rule of Saint Benedict and founded a sizeable congregation ${ }^{5}$.

Greater Poland (Wielkopolska) was one of the regions of the Commonwealth where Reformation ideas emerged quite early. As early as the mid-16th c., Poznań and its environs

\footnotetext{
1 The monastery chronicle started only ca. 40 years after the foundation. It covered the period since the foundation till ca. 1780. The chronicle came out in print. See Kroniki Benedyktynek Poznańskich, ed. M. Borkowska, W. Karkucińska, J. Wiesiołowski, Poznań 2010, pp. 31-34.

2 J. Gwioździk, "Kultura umysłowa benedyktynek kongregacji chełmińskiej w okresie staropolskim", w: Sanctimoniales. Zakony żeńskie w Polsce i Europie Środkowej, ed. A. Radzimiński, D. Karczewski, Z. Zyglewski, Bydgoszcz-Toruń 2010, p. 481.

3 K. Górski, Matka Mortęska, Kraków 1971, p. 19.

4 Magdalena Mortęska - b. 1554, d. 1631. Daughter of Chamberlain of Malbork Melchior Mortęski and Elżbieta née Kostka. A relative of Bishop Piotr Kostka. A reformer of the Benedictine sisters, she created a congregation of 20 monasteries. See K. Górski, "Magdalena Mortęska i jej rola w reformie trydenckiej w Polsce", Nasza Przeszłość, 34/1971, pp. 131-176.

5 However, it was not a congregation in the full sense of the word, as it did not have a single, central governance structure. However, one can speak of a certain bond between individual congregations, manifested even in mutual correspondence; see M. Borkowska, Zakony żeńskie w Polsce w epoce nowożytnej, p. 140.
} 
were settled by Lutherans, Calvinists, Arians, and the Czech Brethren ${ }^{6}$. New denominations attracted both burghers and representatives of eminent Poznań-based families, including Ostroróg, Gostomski and Górka. A case in point is Andrzej Górka ${ }^{7}$, whose Palace in Old Market Square housed a Lutheran Church since 1540, active intermittently almost till the end of the 16 th $\mathrm{c}^{8}$. The Palace went down in history as one of the major centres of the Reformation in Greater Poland, mainly because of the three Protestant synods taking place on its premises ${ }^{9}$. As already indicated, the Palace was conveniently located in the Poznań Old Market Square, bound by today's streets Wodna, Klasztorna and Kozia ${ }^{10}$. The building, the chief property of the Górka family, was linked via a balcony passage with the buildings on the other side of the street.

Encouraged by Anna Petrusówna, an affluent burgher from Poznań, the abbess of Chełmno decided to fund a new monastery of the Chełmno congregation in Poznań. To this end, in 1605 she went to the city where, having consented to the conditions put forth by the burghers of Poznań, she purchased the Górka Palace and the neighbouring tenement house ${ }^{11}$. The conversion of the buildings proceeded fast and as early as 1607 five nuns arrived here from $\mathrm{Chełmno}^{12}$. The first Holy Mass in the monastery was celebrated that very year, on November $1^{13}$. Slightly later, on 10 July 1609, when the monastery was consecrated by Bishop of Poznań Andrzej Opaliński ${ }^{14}$, it was home to as many as thirteen nuns, an adequate number to assign all offices ${ }^{15}$. The most significant one, of the abbess, was assumed by Dorota Żerońska ${ }^{16}$.

The history of the Benedictine monastery in the capital of Greater Poland came to an end in 1835, when the Prussian authorities dissolved the congregation ${ }^{17}$. Although the last abbess Weronika Sobocka ${ }^{18}$ died in 1828 , the position of the prioress was vacant for seven years.

\footnotetext{
6 M. Serwański, "Formy aktywności kolegium jezuickiego w Poznaniu w XVI-XVIII wieku”, Mazowieckie Studia Humanistyczne, 2/2002, p. 31.

7 Andrzej Górka (1500-1551) - Castellan of Poznań and General Starost of Wielkopolska. See W. Dworzarzek, Andrzej Górka, in: Wielkopolski Stownik Biograficzny, Warszawa-Poznań 1981, pp. 217-218.

8 The Czech Brethren also held their religious services in the Palace and following the $1551 \mathrm{flood}$, the Palace was a venue of Catholic Holy Masses; see T. Jakimowicz, Pałac Górków w Poznaniu, Poznań 1998, p. 27.

9 Ibidem, p. 28.

10 W. Knapowska, Dzieje fundacji Ludwiki Radziwiltowej w Poznaniu, Poznań 1930, p. 60.

11 These conditions were as follows: the daughters of the Poznań burghers were to study at the monastery school and were admitted to the monastery without any difficulty. Additionally, the sisters were to pray for the deceased founders; see Kroniki Benedyktynek Poznańskich, pp. 31-34.

12 These were: Anna Nietaszkowska, Dorota Przepałkowska, Barbara Grocholska, Zofia Kilińska, and Dorota of Wągrowiec. See ibidem, p. 36.

13 Ibidem, p. 36.

14 Andrzej Opaliński - b. 1575. Bishop of Poznań since 1607 till his death in 1623. See S. Ochmann, Andrzej Opaliński, in: Wielkopolski Stownik Biograficzny, Warszawa-Poznań 1981, p. 529.

15 Kroniki Benedyktynek Poznańskich, p. 41.

16 Dorota Żerońska - took holy vows in 1610 in the Chełmno monastery, subsequently sent by Abbess Mortęska to Poznań. D. 1637 in the Poznań monastery. See M. Borkowska, Stownik polskich ksień benedyktyńskich, Niepokalanów 1996, p. 188-189.

17 Eadem, Stownik mniszek benedyktyńskich w Polsce, Tyniec 1989, p. 90.

18 Weronika Sobocka - the last abbess of the Poznań monastery. Only the dates of her benediction and death are known, 1776 and 1828, respectively. See eadem, Stownik polskich ksień benedyktyńskich, p. 148.
} 


\section{The convent and monastery of Benedictine nuns in Poznań during a flood and "elementary" disasters}

Cloistered nuns were not oblivious of the world at large. Local or nationwide events impacted the life of the monastery. Such out-of-the-ordinary events included epidemics or disasters, which frequently disrupted the daily rhythm of monastic life.

The Old Polish term for a plague, or incidence of a particular illness within a given area, was powietrze or air ${ }^{19}$. Epidemics were most often accompanied by harsh weather conditions, such as droughts or floods. Prolonged military presence in a given area or marches through it were a special kind of disaster ${ }^{20}$. Such events made everybody equal during and all were equally panicked. Jan Kracik observes that the fear instilled by the perspective of death during a plague divided people and made them choose between heroism and cowardice ${ }^{21}$.

The area of Wielkopolska and Poznań itself were throughout the 17th and 18th centuries plundered a few dozen times by all kinds of disasters. For example, between 1501 and 1785 there were as many as 39 floods, which means that the River Warta overflowed its banks and submerged at least a section of the city every seven years ${ }^{22}$. Between 1648 and 1696 the population of Greater Poland was eight times struck by a plague, as identified by the author of this article ${ }^{23}$. This is confirmed by the monastery chronicle, which lists epidemics every six years ${ }^{24}$. This does not mean that each time such phenomena occurred, they directly impacted the Poznań-based chetmionki ${ }^{25}$. The chronicler recorded only two floods ${ }^{26}$ and five other occurrences which devastated Poznań or the monastery-owned villages ${ }^{27}$.

The first flood which Sr. Joanna Jaskólska ${ }^{28}$ recorded took place in late March and early April 1612. ${ }^{29}$ Due to the thaw, the River Warta rose above the flood banks and submerged the old market square and many adjacent streets. The monasteries of Bernardine sisters, Bernardine friars and Carmelites were the hardest hit ${ }^{30}$. The disaster not only devastated the city but also claimed many lives of those who drowned in the water. The water level was so high that the services of the Paschal Triduum ${ }^{31}$ were transferred from the Old Town Parish Church to the Benedictine Sisters' Church ${ }^{32}$.

\footnotetext{
19 A. Karpiński, $W$ walce z niewidzialnym wrogiem. Epidemie chorób zakaźnych w Rzeczypospolitej w XVI-XVIII wieku i ich następstwa demograficzne, społeczno-ekonomiczne i polityczne, Warszawa 2000, p. 20.

20 S. Namaczyńska, Kronika klęsk elementarnych w Polsce i w krajach sąsiednich w latach 1648-1696, Lwów 1937, p. 28*.

21 J. Kracik, Staropolskie postawy wobec zarazy, Kraków 2012, p. 5.

22 A. Kaniecki, Poznań. Dzieje miasta woda pisane, Poznań 2004, p. 426.

23 S. Namaczyńska, op. cit., passim.

24 Kroniki Benedyktynek Poznańskich, p. 70.

25 This was a nickname for the Benedictine nuns from Poznań, see J. Łukaszewicz, Krótki opis kościołów parochialnych $w$ dawnej diecezji poznańskiej, Poznań 1858, p. 103.

26 Kroniki Benedyktynek Poznańskich, pp. 50, 137-138.

27 Ibidem, pp. 60, 69, 73, 75-76, 149-154.

28 Joanna Jaskólska - in the novitiate since 1638. Took holy vows in 1639. Died in Trzebnica in 1656, where she lived during the Swedish War. See M. Borkowska, Leksykon zakonnic polskich epoki przedrozbiorowej, vol. 1: Polska zachodnia i pótnocna, Warszawa 2004, p. 85.

${ }_{29}$ Kroniki Benedyktynek Poznańskich, p. 50.

30 A. Kaniecki, op. cit., p. 426.

31 Triduum Paschalne of 1612 took place between April 19 and 22.

32 Kroniki Benedyktynek Poznańskich, p. 50.
} 
The monastery of the Benedictine nuns in Poznań must have been a safe haven since until the water subsided, it offered shelter to the Bernardine sisters ${ }^{33}$. Poor Clares, or Sisters of St. Clare as the chronicler called them, lived in the monastery infirmary. Sr. Jaskólska recorded that they were rather diligent in their religious observance and did the same as the Benedictines. They prayed together, recited the Lauds and participated in the Holy Masses celebrated by a Bernardine friar, as these men religious provided pastoral care to the Poor Clares ${ }^{34}$. Living together generated conflict. The Bernardine nuns, very ungrateful towards their hosts, spread rumours, as the chronicler recorded, on what was going on in the monastery of the Benedictine nuns. The latter were alleged, for example, to wear veils on wires. Ultimately, the conflict was resolved thanks to the mediation of a Bernardine friar, notified about the entire situation by Abbess Żerońska. Although the Bernardine nuns apologised, a decision was taken never to host sisters from other congregations again ${ }^{35}$. The Poor Clares returned to their monastery only on 10 April 1612.36

The above decision was not implemented, though. When another flood devastated Poznań in March 1651, the convent and church of the Bernardine nuns was destroyed ${ }^{37}$. The flood must have wreaked havoc in the city as the water level at the Poor Clares' church was over one meter high ${ }^{38}$. Only two sisters moved in with the Benedictine nuns; these were Katarzyna Czarnkowska $^{39}$ and Magdalena Więckowska ${ }^{40}$. The latter, having befriended a nun from Poznań, helped her to submit a letter to the bishop, signed by another fourteen nuns living in the Górka Palace ${ }^{41}$. Ultimately, however, the letter was not submitted as news about it reached Abbess Głoskowska ${ }^{42}$.

The life of the Poznań Benedictine nuns' monastery was visibly influenced, though not always directly, by epidemics and pestilence, also classified as "elementary" disasters. Currently, it is assumed that the term applied to diseases such as plague, diarrhoea and typhus ${ }^{43}$. The first information about the plague was recorded by Sr. Jaskólska in 1621. However, it does not relate to Poznań itself, but to Goślina, one of the villages belonging to the monastery. According to the chronicler, the plague claimed a heavy death toll; combined with drought and famine ${ }^{44}$ of the following year, it had dire consequences and significantly affected the financial standing of the monastery ${ }^{45}$. Instead of providing sustenance, the property turned into a nuisance for the nuns as they themselves had to provide for the inhabitants of

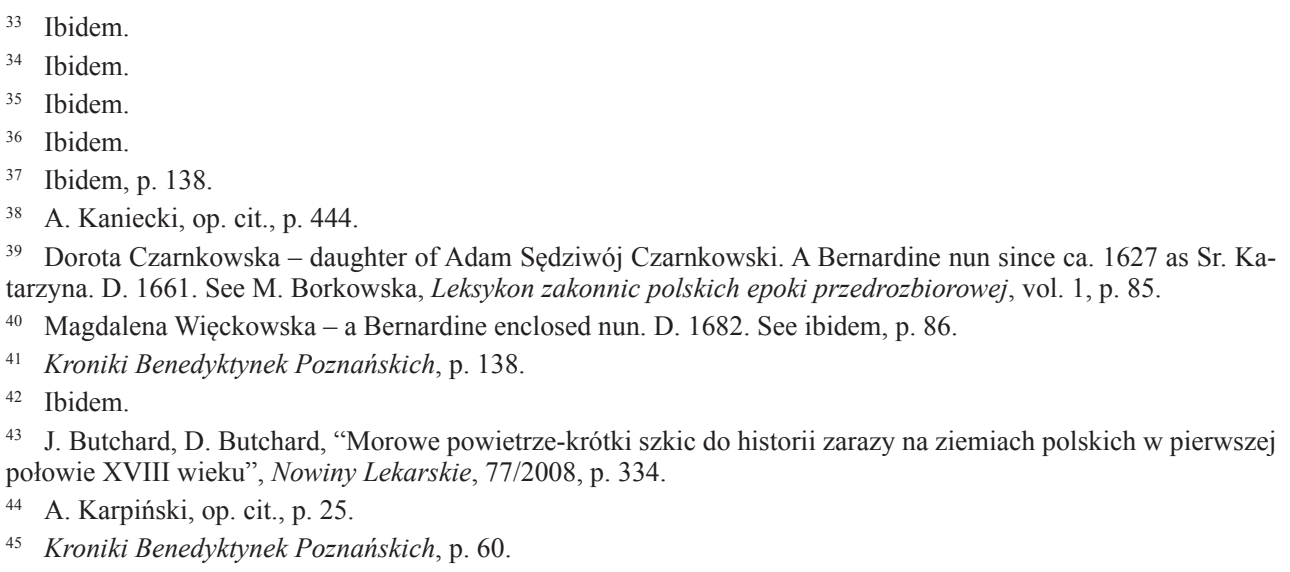


Goślina ${ }^{46}$. The chronicler did not specify the type of the disease that hit the village in 1621, but since the summers in that period were exceptionally wet, it can be assumed that it was plague, typhoid or dysentery ${ }^{47}$.

The description of the first plague was rather scanty and does not convey any information about the life of the monastery during the epidemic. The account from 1624 provides more details. At that time, the Benedictine nuns' convent was directly affected by the plague that spread in Poznań. After the mayor's visit to the monastery, the nuns decided to move to the countryside. Those unable to make the trip were to be looked after by the mayor himself. Abbess Żerońska and most nuns left on 1 December 1624, but the destination of the group was not recorded.

The chronicler gave a rather extensive description of what monastic life looked like during the plague. The nuns prayed as they had done in Poznań; the sisters were divided into two choirs and in this way they recited the Lord's Grace ${ }^{48}$. The nuns would walk to the church along a road specially prepared by the villagers, but they had to wear not only veils, but also the cappas and novices' scarves. The sisters received the Holy Sacraments in a twofold manner. At the very beginning, Penance and the Eucharist were held every Sunday and every feast day, and the nuns would confess through the grille in the church door. Soon, because of the low temperatures and the nuns' discomfort, the villagers built a gate in the manor house, where the sacrament of penance was administered from that time on ${ }^{49}$.

In time, as the death toll rose, the measures to protect the nuns and their chaplains against the contagion grew more stringent. Ever since, the nuns confessed their sins out loud to the priest standing on the other side of the fence. Holy Communion was administered through a smoke screen separating the sister and the priest ${ }^{50}$. Another factor to prevent sisters from dying from the epidemic was to eat toast with vinegar and herbs. However, it was not an effective cure and had its side effects, i.e. caused stomach aches ${ }^{51}$.

All the above precautions failed to produce the desired effect and three sisters, Anna

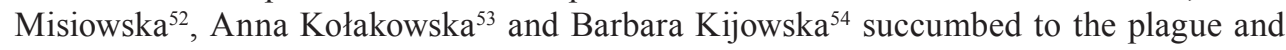
were buried in Goślina. Extreme cold proved an ally in the fight against the germs and in late January and early February of 1626 the sisters returned to Poznan ${ }^{55}$. However, the effects of the plague were felt for a long time. The harvest was so poor that people were not only unable to grow the grain they had sown, but there were no wild roots that the poorest people fed on $^{56}$. Only the vegetables sown in the monastery garden grew well, but not enough to

\footnotetext{
46 Ibidem, p. 60.

47 A. Sokołowski, Wielkie klęski społeczne i walka z niemi, Warszawa 1917, p. 114.

48 Kroniki Benedyktynek Poznańskich, p. 69.

49 Ibidem.

50 Ibidem.

51 Ibidem, p. 70.

52 Anna Misiowska - a novice since 1623, professed the following year. D. 1626. See M. Borkowska, Leksykon zakonnic polskich epoki przedrozbiorowej, vol. 1, p. 81.

53 Anna Kołakowska - began her novitiate in Chełmno in 1594, consecrated in 1601, novice mistress in Poznań. See ibidem, p. 81.

54 Barbara Kijowska - a novice since 1615, professed in 1616, died ten years later. See ibidem, p. 79.

55 Kroniki Benedyktynek Poznańskich, p. 70.

56 Ibidem, p. 73.
} 
feed the entire convent and all those in need. The sisters, however, could not do anything else, and having indebted the monastery for three thousand zlotys, began feeding the poor. They had so much work that there was barely time for peeling vegetables and praying ${ }^{57}$. The epidemic and the resultant famine claimed a total of 6,000 lives of the city residents ${ }^{58}$.

We can safely say that the plague which began in 1625 continued until 1630, when another outbreak of it was recorded in Poznań. The first symptoms were the death of Fr. Wit, a confessor of the Benedictine nuns, and of Sr. Helska, a servant of the convent. Elżbieta Poniecka, who was living in Łoskon, a village belonging to the convent, went down with the illness, too. The sisters from the monastery decided to head for Promno, but all the servants escaped at the sight of them ${ }^{59}$. The religious life of the nuns was very similar to that during the 1625 pestilence. The exceptional circumstances did not exempt the nuns from the observance of the Rule and the performance of their duties, i.e. primarily payer and incessant self-betterment. This was highlighted by Abbess Głoskowska in her recommendations for the nuns leaving for the countryside ${ }^{60}$.

Confessions were heard in an orchard, yet no longer through a billow of smoke, like before. There was a spruce tree between the confessor and the nun. To preserve the seal of confession, the nuns had to go to the orchard one by one. When Elżbieta Ponińska ${ }^{61}$ presented with the first symptoms of the disease, she was administered the Eucharist through smoke. After she died, nuns Teofila Rozrażowska ${ }^{62}$ and Anna Bąkowska ${ }^{63}$, who dressed her body for internment, were quarantined. Two wooden sheds were erected in the orchard and the nuns were to live there for a few weeks. Food was brought to them, yet they were now allowed to touch the vessels before the person who had brought them food left ${ }^{64}$. Apart from Sr. Ponińska, also Zofia Dobruchowska ${ }^{65}$ died, yet unlike the former was buried in a coffin and in the church in Goślina rather than in a cemetery ${ }^{66}$.

The years 1652-1653 were a time of plague across Europe ${ }^{67}$. This was most likely dysentery, whose symptoms were identified in Sweden ${ }^{68}$. The epidemic reached the region of Greater Poland and Poznań in 1653, when its symptoms were first noticed among students

57 Ibidem.

58 Z. Boras, L. Trzeciakowski, W dawnym Poznaniu, Poznań 1971, p. 160.

59 Kroniki Benedyktynek Poznańskich, p. 76.

60 Ibidem.

61 Elżbieta Ponińska - a novice since 1610, professed the following year. D. 1630. See M. Borkowska, Leksykon zakonnic polskich epoki przedrozbiorowej, vol. 1, p. 78.

62 Teofila Rozrażowska (Rozdrażewska) - a novice since 1626, professed in 1627, consecrated the following year.

D. 1653. See ibidem, p. 81 .

63 Anna Bąkowska - in the monastery since 1628, professed in 1629, consecrated in 1638. D. 1670. See ibidem, pp. 82-83.

64 Kroniki Benedyktynek Poznańskich, p. 75.

65 Zofia Dobrochowska (Dąbrowska) - novice in Poznań in 1612, profession and consecration took place year after year. D. 1630. See ibidem, p. 78.

${ }_{66}$ Kroniki Benedyktynek Poznańskich, pp. 75-76.

67 S. Namaczyńska, op. cit., p. 129.

68 Ibidem, p. 132. 
of the Jesuit college ${ }^{69}$. The situation in the city was made worse by the influx of visitors participating in a Forum Nobilium ${ }^{70}$.

Under the circumstances, a decision was taken in the monastery to leave the capital of Wielkopolska. The first to leave were Zofia Tuczyńska ${ }^{71}$ and Zofia Szołdrska ${ }^{72}$, the subprioress, and three other nuns ${ }^{73}$. Their first stopover was a village near Poznan and the final destination was to be Tuczyn near Zbąszyń. As the plague did not spread and actually receded, the nuns decided to stay in Zbąszyń and remained there for four weeks ${ }^{74}$.

The bishop's consent was needed for the other nuns remaining in the monastery to seek shelter outside, as this violated the cloister. The abbess started to seek the consent of Bishop Florian Czartoryski only when the pestilence got dangerously close to the monastery. It was only the second request, however, and the explanation to the bishop of all the problems related to the relocation of the nuns that secured the ordinary's approval. The abbess sent only a few sisters each time and herself went to Promno ${ }^{75}$. The last group left the monastery a bit later, after all the valuable objects had been hidden and the keys deposited at the gate ${ }^{76}$. Nine nuns remained in the Górka Palace, including four aged ones, three sick ones (one mentally ill), a gatekeeper, and one younger sister. They were to be served on by three secular sisters. One of them, Sr. Rozrażowska ${ }^{77}$, died soon afterwards ${ }^{78}$.

Until all the nuns succumbed to the plague, Holy Mass in the monastery church was celebrated by a priest from the Poznan old city parish church ${ }^{79}$. Five of the nuns remaining in the monastery died as a result of the disease. The transmission route, despite the isolation, is unknown. The chronicler suspects that either the smoke from the bonfires kindled on the old market reached them or else their death was a punishment for failure to observe the lockdown and leaving the monastery to purchase food and other items ${ }^{80}$.

\section{Wars and presence of armies and their impact on the Poznań monastery of the Benedictine nuns}

Wars and soldiers' presence in cities were other unusual events which affected almost the whole society, including cloistered nuns and monks. Marches of troops through or their stationing in the city were a nuisance to the inhabitants of the Commonwealth of Poland

\footnotetext{
69 Kroniki Benedyktynek Poznańskich, p. 149.

70 Ibidem, pp. 149-150.

71 Zofia Tuczyńska - daughter of the Chamberlain of Inowrocław, a novice since 1649, novice mistress, subprioress and prioress, d. 1705. See M. Borkowska, Leksykon zakonnic polskich epoki przedrozbiorowej, vol. 1, p. 86.

72 Zofia Szołdrska - novice as of 1626, professed in 1627. Abbess of the Poznań monastery since 1669. D. 1692. See ibidem, p. 82; M. Borkowska, Stownik polskich ksień benedyktyńskich, p. 159.

73 Kroniki Benedyktynek Poznańskich, p. 150.

74 G.J. Brzustowicz, “Genealogia Tuczyńskich de Wedel: część 2 (XVII - pocz. XVIII w.)”, Nadwarciański Rocznik Historyczno-Archiwalny, 13/2006, pp. 102-103.

75 Kroniki Benedyktynek Poznańskich, p. 150.

76 Ibidem.

77 Jadwiga Rozrażewska - sister of Teofilia and Agnieszka, Benedictine nuns from Poznań. See M. Borkowska, Leksykon zakonnic polskich epoki przedrozbiorowej, vol. 1, p. 79.

78 Kroniki Benedyktynek Poznańskich, p. 150.

79 Ibidem, p. 151.

80 Ibidem, p. 151.
} 
and Lithuania not only when the city became the enemy's prey. The army is made up of a large number of people who are more susceptible to all kinds of infectious diseases, and what is more, they can infect the local population. Secondly, a longer stay of an army in any area has always meant economic regress and destruction of property. The war fed itself, which meant that the soldiers had to acquire food by collecting it from the local people. In this way, the enemy armies also gained firewood or more expensive things. The chronicle records three times the events connected with warfare and the stationing of foreign armies in Wielkopolska. Each time the events described concerned Swedish soldiers.

The Swedish policy, aimed at conquering the shores of the Baltic and at making it an internal sea, turned out to be disastrous for the nuns from the Benedictine convent of the Chełmno congregation in Bysławek ${ }^{81}$. In 1626, King Gustav Adolf of Sweden along with his numerous fleet and army began the war and landed in Pomerania ${ }^{82}$. The initial defeats of King Sigismund III Vasa indicated to the nuns from Bysławek that they should flee. They had all their belongings they could carry packed and the livestock prepared, fearing that they would have nowhere to return to ${ }^{83}$. A great many of them arrived in Poznan since the monastery numbered fifty nuns. The nuns from Bysławek were accepted as confreres rather than as guests. They participated in Holy Mass and received the sacraments with the Poznań sisters and participated in the chapter together. They felt obliged to reciprocate the hospitality extended to them and when living in the Górka Palace, they waited on the local nuns ${ }^{84}$.

The nuns from Bysławek lived in Poznań for a short spell of three months, between July 26 and October $4^{85}$. The possibility of returning to their own monastery was closely linked to the situation of the troops and emerged only after the deterioration of the situation of the Swedes ${ }^{86}$.

Sr. Jaskólska recorded also the events of the Second Swedish War. Abbess Ewa Głoskowska knew about the Swedish plans to invade Poland a bit earlier ${ }^{87}$. Having heard the news from a merchant from Poznań, she decided to prepare the nuns for a departure from town ${ }^{88}$. In the course of the preparations the abbess visited a monastery of Cistercian sisters in Trzebnica ${ }^{89}$,

81 A Benedictine monastery of the Chełmno congregation founded by Magdalena Mortęska in 1602 was in Bysławek. See A. Brygman, Klasztor Benedyktynek w Bysławku 1602-1836, in: Sanctimoniales. Zakony żeńskie w Polsce i Europie Środkowej (do przełomu XVIII i XIX wieku), ed. A. Radzimiński, D. Karczewski, Z. Zyglewski, Bydgoszcz-Torun 2010, p. 321.

82 L. Podhorecki, Rapier i koncerz, Warszawa 1985, p. 120.

83 Kroniki Benedyktynek Poznańskich, p. 74.

84 Ibidem, p. 74.

85 Ibidem, p. 75.

86 L. Podhorecki, op. cit., p. 133.

87 Ewa Głoskowska - professed in Poznań in 1629. Abbess of the monastery since 1651. The Swedish War broke out when she was prioress and she was forced to evacuate the nuns to Silesia. D. 1665. The chronicle lists her also as Magdalena Głoskowska, the name she probably assumed after her benediction. See M. Borkowska, Stownik polskich ksień benedyktyńskich, p. 39.

88 Kroniki Benedyktynek Poznańskich, p. 74.

89 Cistercian nuns' monastery in Trzebnica, the earliest foundation of Cistercian nuns on Polish soil. In 1202 Prince Henry I the Bearded with his wife, St. Hedwig founded a monastery and the following year Cistercian nuns from Bamberg settled there. In 1810 the monastery was secularised. As of 1889 the former monastery buildings were taken over by the Sisters of Mercy of St. Borromeo, who have lived there since. See M. Kanior, "Pierwsze fundacje cysterek na ziemiach polskich", in: Cysterki w dziejach i kulturze ziem polskich, dawnej Rzeczypospolitej i Europy Środkowej. Materiały z siódmej Międzynarodowej Konferencji Cystersologów odbytej z okazji 800. Rocznicy fundacji opactwa cysterek w Trzebnicy. Trzebnica 18-21 września 2002 r., ed. A.M. Wyrwa, A. Kiełbasa, J. Swastek, 
Silesia, outside the Polish borders, wishing to learn if she and the other nuns could wait out the war there. Importantly, the Swedes entered Greater Poland in the spring of 1655 and before long invaded the entire region ${ }^{90}$.

The prioress from Poznań received an affirmative answer from the abbess from Trzebnica Dorota Bnińska ${ }^{91}$. On returning to Poznań and learning about the surrender of Poles at Ujście, Abbess Głoskowska had the liturgical vestments and utensils as well as other objects packed $^{92}$. Four sisters were dispatched to Trzebnica: Zofia Szołdrska, Barbara Święcicka ${ }^{93}$, Anna Trąpczyńska ${ }^{94}$, and Anna Żychlińska ${ }^{95}$. Their itinerary included Trzebisławek and Chrzątów, where it turned out that all four could not make it to the Cistercian monastery. Ultimately, only Sr. Szołdrska and Sr. Święcicka continued their journey, having acquired horses ${ }^{96}$. Having reached their destination, the nuns saw that the circumstances were different than in May, when Abbess Głoskowska had visited Trzebnica. This time Abbess Bnińska refuse to give shelter to the nuns from Poznań, indicating that she must accommodate those from the monastery in Owińska. Under these circumstances the nuns moved in with Mrs. Konarska, a cousin of Zofia Szołdrska's ${ }^{97}$. two others went to the Poor Clares' monastery in Srem ${ }^{98}$. This was also the destination of Sr. Katarzyna Swinarska, who carried the objects taken from Poznań, but all of them were robbed by the Swedes ${ }^{99}$.

The nuns stayed in Śrem around three weeks and then decided to go to Trzebnica, hoping to meet their abbess there ${ }^{100}$. They managed to do it on September 15 that year, thanks to the assistance of Piotr Przyjemski. At that time the parents of Sr. Anna Bąkowska wrote the abbess, requesting her to let their daughter come to them, as they wished to die in the company of their only living child ${ }^{101}$. Sr. Anna went to her family home with Regina Tomisławska ${ }^{102}$ and Jadwiga Kwiatkowska ${ }^{103}$. Having reached Ostrzeszów and seeing the

Poznań 2004, pp. 39-51, B. Stellmach, Kontynuacja historii klasztoru Cysterek w Trzebnicy, in: ibidem, pp. 540-549 .

90 J. Topolski, Wielkopolska poprzez wieki, Poznań 1999, pp. 118-119.

91 Abbess of Trzebnica between 1653 and 1659. D. 1661. See M. Borkowska, "Skład osobowy polskich klasztorów cysterek w XVII-XVIII w.”, in: Cysterki w dziejach i kulturze ziem polskich, dawnej Rzeczypospolitej i Europy Środkowej. Materiały z siódmej Międzynarodowej Konferencji Cystersologów odbytej z okazji 800. Rocznicy fundacji opactwa cysterek w Trzebnicy. Trzebnica 18-21 września 2002 r., op. cit., p. 67.

92 Kroniki Benedyktynek Poznańskich, p. 157.

93 Barbara Święcicka - a novice in 1647, professed in 1650. D. 1658 before consecration. See M. Borkowska, Leksykon zakonnic polskich epoki przedrozbiorowej, vol. 1, p. 86.

94 Anna Trąpczyńska - a novice as of 1626, consecrated two years later. See ibidem, p. 82.

95 Anna Żychlińska - a novice as of 1651, profession in 1652. Consecrated after her return to Poznań in 1659. See ibidem, p. 86.

96 Ibidem, p. 159.

97 Ibidem, p. 159.

98 The monastery of the Poor Clares in Śrem earlier belonged to Franciscan friars. The Poor Clares lived there between 1623 and 1855, when the Jesuits took over. See B. Śmigalski, Śrem, in: Encykloepdia Katolicka, vol. 19, Lublin 2013, chart 298.

99 Kroniki Benedyktynek Poznańskich, p. 159-160.

${ }^{100}$ Ibidem, p. 160.

${ }^{101}$ Ibidem, p. 157.

102 Regina Tomisławska - in the monastery since 1627, professed and consecrated in 1628. D. 1688. See

M. Borkowska, Leksykon zakonnic polskich epoki przedrozbiorowej, vol. 1, p. 82.

103 Jadwiga Kwiatkowska - in the novitiate since 1628, professed in 1629, consecrated 9 years later. D. 1685. See ibidem, p. 82. 
discontent of Anna Bąkowska's parents due to the fact that their daughter had company, Sr. Tomisławska decided to move in with her own parents and wait out the war there. All the three nuns survived the entry of the Swedes to Greater Poland; the first one spent five years with her brother after their parents died, and the other lived for three and a half years with Sr. Tomisławska's mother ${ }^{104}$. Later on Sr. Kwiatkowska moved in with Teresa Opalińska yet was robbed of all her possessions there ${ }^{105}$. Sr. Katarzyna Szwejkowska went to live with her relatives and was accompanied by Sr. Anna Bukowiecka. Moreover, Zofia Grabowiecka ${ }^{106}$ and Barbara Marszewska ${ }^{107}$ were accommodated by the former's relative, who interestingly was a Lutheran ${ }^{108}$.

Abbess Głoskowska had problems leaving the monastery. Although the entire city was deserted and the only sound in the streets were cries urging others to escape, Bishop Florian Czartoryski did not allow the remaining nuns to seek shelter from the Swedes outside their monastery ${ }^{109}$. The bishop's consent came only on July 26, handed over by Fr. Chancellor Andrzej Swinarski. Before leaving the cloister of their monastery, each Benedictine nun confessed her sins and then received Holy Eucharist ${ }^{110}$. Setting out on the journey were a total of fourteen nuns, five lay sisters, an apprentice, and a carter ${ }^{111}$. Leaving the monastery, the abbess took four carts of different objects; one carried silverware only. Due to the lack of means of transport, the nuns had to walk the whole way to Trzebisławki. Only Abbess Głoskowska and two nuns, Katarzyna Centalonka ${ }^{112}$ and Anna Gablińska, ${ }^{113}$ rode on a cart. Their itinerary was different from that of the sisters who had left for Trzebnica earlier. They first arrived in Trzebisławki, then in Czarnotki, Dubin and finally Trzebnica ${ }^{114}$. As before, this time too Abbess Bnińska decisively refused to accept the nuns and the abbess, despite earlier arrangements. She relented and accepted five nuns only after much begging and entreating ${ }^{115}$.

The eight nuns who could not find adequate accommodation remained in Dubin. They settled in a palace prepared for them by Katarzyna Opalińska née Leszczyńska ${ }^{116}$. Ultimately, Abbess Głoskowska managed to find accommodation for them in the Legnica ${ }^{117}$

\footnotetext{
104 Kroniki Benedyktynek Poznańskich, p. 158.

105 Ibidem, p. 159.

106 Zofia Grabowiecka - in the novitiate since 1633, took holy profession two years later, consecrated after another three years. D. 1673. See M. Borkowska, Leksykon zakonnic polskich epoki przedrozbiorowej, vol. 1, p. 84.

107 Barbara Marszewska - in the monastery since 1651, professed in 1653. Consecrated in 1659. D. 1708. See ibidem, p. 85.

108 Kroniki Benedyktynek Poznańskich, p. 162.

109 Ibidem, p. 160.

110 Ibidem, p. 161.

111 Ibidem, p. 162.

112 Katarzyna Centalonka - in the monastery since 1629, professed that year, too. Consecrated in 1638. D. 1665. See M. Borkowska, Leksykon zakonnic polskich epoki przedrozbiorowej, vol. 1, p. 83.

113 Anna Gablińska - in the monastery since 1633, professed in 1635. D. 1678. See ibidem, p. 84; Kroniki Benedyktynek Poznańskich, p. 162.

114 Ibidem, p. 162.

115 Ibidem, p. 162.

116 Ibidem, p. 163.

117 The monastery in Legnica was founded in 1348 by the Dukes of Legnica. See M.R. Górniak, Legnica, in: Encyklopedia Katolicka, vol. 10, Lublin 2004, chart 673-676.
} 
and Lubomierz ${ }^{118}$ monasteries, where their only concern was, according to the chronicler, to be able to go to confession in the Polish language ${ }^{119}$. Four nuns lived in Lubomierz and they fared much better than the nuns from Legnica and Trzebnica. Although they, too, complained about the shortage of confessors speaking Polish and thus about the inaccessibility of the sacraments, they could not complain about the living standards. They even received money, cloth or shoes from the sisters from Lubomierz and gifts for St. Nicholas Day ${ }^{120}$.

Wishing to know more about what was going on in Poznań, Abbess Głoskowska decided to ask for shelter in the convent of the Poor Clares in Wrocław ${ }^{121}$. The first reply was a refusal as a result of providing a place to live for the sisters from the monastery in Ołobok. Fortunately for the abbess, they met a monk there who agreed to accommodate the nuns in his apartment. Thus the abbess got free shelter near the Wrocław monastery of the Norbertines in Piasek $^{122}$. Before long it turned out that a transfer to Wrocław was indispensable. Because of the proximity of Trzebnica to the Polish border, the town ceased to offer safe shelter, either. Abbess Głoskowska left Trzebnica and was shortly followed by Elżbieta Czekanowska ${ }^{123}$ and Zofia Barska ${ }^{124}$, who moved in with Anna Dębiczowa, mother of one of the nuns ${ }^{125}$. On July 27 the following year, Sr. Joanna Jaskólska, the monastery chronicler, died in the monastery in Trzebnica ${ }^{126}$. Within a short time of her burial, a plague broke out in Trzebnica and the nuns had to set on the road again. Teresa Trąpczyńska went to live with her uncle and the others were ordered by the abbess to go to Wrocław. On 22 October 1656 they left for Lubomierz and then for Laben ${ }^{127}$. This did not end the wanderings of the nuns; on Easter 1657, the abbess managed to secure the transfer of Katarzyna Szwejkowska and Zofia Turczyńska to the monastery in Nambork, Silesia. Because of the poor living conditions in the monastery, the nuns did not stay there long; Sr. Szwejkowska was transferred to Lubomierz and Sr. Turczyńska remained with the abbess in Wrocław ${ }^{128}$.

The monastery in Poznań was not completely vacated and nine nuns remained: Zofia Cielecka $^{129}$, Elżbieta Czekanowska, Anna Zbyszewska ${ }^{130}$, Zofia Barska, Anna Gablińska ${ }^{131}$,

${ }^{118}$ The monastery was founded in 1278. As of 1863 , the former Benedictine buildings were taken over by the Sister of St. Elisabeth. See K. Małysz, Lubomierz, in: Encyklopedia Katolicka, vol. 11, Lublin 2006, chart 66.

${ }^{119}$ Kroniki Benedyktynek Poznańskich, p. 163.

${ }^{120}$ Ibidem, pp. 166-168.

${ }^{121}$ The monastery of the Poor Clares in Wrocław was founded in 1257 by Princess Anna, wife of Henry the Pious. In 1810 the monastery was taken over by the Ursuline nuns. See W. Bochnak, Księżna Anna Śląska 1204-1265 w stużbie ludu Ślaskiego i Kościoła, Wrocław 2007, pp. 245-246.

122 Kroniki Benedyktynek Poznańskich, p. 168.

${ }^{123}$ Elżbieta Czekanowska - novitiate and profession in Chełmno in 1607, consecration in Poznań. D. 1670. See ibidem, p. 283.

124 Zofia Barska - novitiate in 1627, profession in 1630. Consecrated in Poznań in 1645, d. 1658. See M. Borkowska, Leksykon zakonnic polskich epoki przedrozbiorowej, vol. 1, Warszawa 2004, p. 85.

125 Ibidem, p. 163.

126 Ibidem, p. 180.

${ }^{127}$ Ibidem, pp. 181-182.

${ }^{128}$ Ibidem, p. 183.

129 Zofia Cielecka - in the novitiate since 1629, professed in 1632. Custodian and sacristan. D. 1664. See M. Borkowska, Leksykon zakonnic polskich epoki przedrozbiorowej, vol. 1, pp. 83-84.

130 Anna Zbyszewska - novitiate in Poznań in 1614, profession the following year, consecration in 1628. Submistress of the layity, custodian and prioress. D. 1665. See ibidem, p. 79.

${ }^{131}$ Anna Gablińska - in the novitiate since 1633, professed in 1635. Sacristan. See ibidem, p. 84. 
Agnieszka Soszczonka ${ }^{132}$, Zofia Węglińska ${ }^{133}$, Dorota Gryszczanka ${ }^{134}$, and Anna Różycówna ${ }^{135}$. The Swedes entered Poznań as early as 26 July 1655, after the nuns escaped ${ }^{136}$. The army of Charles X Gustav of Sweden pillaged the city. The mayor and the councillors were imprisoned ${ }^{137}$. The priests and men religious left in the city were summoned before Easter 1656 and ordered to leave Poznań. Only three Jesuits were allowed to stay. All the churches on the left bank of the River Warta were destroyed save that of the Benedictine nuns ${ }^{138}$. The monastery and the church were left intact solely with the intention to reconvert the premises to a Lutheran $\operatorname{church}^{139}$. Soon the monastery was plundered, too, and the Swedes stole not only all the silverware and other valuables but also the remaining food ${ }^{140}$. The struggle to recapture the city began only on 24 June 1657 . The nuns were ordered to leave the monastery or else they would be burned with the church. During the night when this was to happen, one of the priests brought the Most Blessed Sacrament to the church, which according to the chronicler saved the Górka Palace from destruction ${ }^{141}$.

Soon afterwards Poznań was recaptured and residents began to return to the city. The first nuns to arrive at the Poznań monastery were: Marianna Brudzińska, Katarzyna Swinarska ${ }^{142}$ and Katarzyna Centalonka ${ }^{143}$. Abbess Głoskowska with Zofia Tuczyńska and Zofia Opalińska returned in September. Magdalena Jaskółczanka and Barbara Marszewska came to the monastery in December, followed by Elżbieta Czekanowska. Nuns from Legnica and Strzegom came in $1658^{144}$. Nuns who had been staying with their families, like Regina Tomisławska, or lived in Lubomierz, like Anna Żychlińska, returned the following year. Some, like Barbara Święcicka or the aforementioned Joanna Jaskólska, never came back home ${ }^{145}$.

The year 1704 was not a happy year for Poznań or Poland, either. Although officially Poland did not take part in the Northern War, a number of battles took place on Polish soil. The capital of Greater Poland suffered particular damage. In 1703 the Swedes managed to take over Poznań and the following year had Stanislaus Leszczyński elected Polish king. The extent of the havoc wreaked on the conquered territory was indeed extensive. According

\footnotetext{
132 Agnieszka Sodczanka (Soszczonka) - in the monastery since 1610, professed in 1611, d. 1662. See ibidem, p. 78 .

133 Zofia Węglińska - professed in 1637, d. 1659. See ibidem, p. 84.

${ }^{134}$ Dorota Gryszczanka - began novitiate in 1638. D. 1685. See ibidem, p. 85.

135 Anna Różycówna - novitiate since 1641, profession in 1642. D. 1678. See ibidem, p. 85.

136 I. Kraszewski, "Stolica po raz ostatni, czyli jak Szwedzi uczynili z Poznania siedzibę dworu królewskiego", in: Jak Czarniecki do Poznania. Wydawnictwo pokonferencyjne z konferencji Jak Czarniecki do Poznania, Poznań 26 IX 2008, Poznań 2009, p. 31.

137 Kroniki Benedyktynek Poznańskich, p. 171.

138 I. Kraszewski, "Stolica po raz ostatni...", p. 32.

139 Kroniki Benedyktynek Poznańskich, p. 174.

140 Ibidem, p. 175.

141 Ibidem, pp. 183-184.

${ }^{142}$ Katarzyna Świejkowska/Szwejkowska - a novice as of 1633, took vows in 1635, consecrated ten years later. An abbess for a short time, she died in 1669. See M. Borkowska, Leksykon zakonnic polskich epoki przedrozbiorowej, vol. 1, p. 84.

143 Kroniki Benedyktynek Poznańskich, p. 184.

144 Ibidem, pp. 191-192.

145 Ibidem, p. 192.
} 
to the monastery chronicle, in 1704 the Swedes decided to dismantle the fence surrounding the monastery garden and used it as firewood ${ }^{146}$. They threatened to cut off the legs of the priest who stood up in defence of the church property. The soldiers mocked the nuns in other ways, too, by dumping in the garden of the Benedectine monastery all the litter, including carcasses of horses. This impeded the flow of the rivulet, which overflowed its banks and submerged the streets near the old market square ${ }^{147}$. After Russia's accession to the war, the situation slowly began to change, even though August II and Russia became victorious only in 1709. Two years later the Russians managed to capture the city. One occupation was replaced by another and the Russians left Poznań only in $1719 .{ }^{148}$ The abbess managed to dispose of the garbage and set the monastery and its surroundings to rights only in 1712 , a few years after the Swedes left town. The wartime destructions were removed only by Abbess Franciszka Ponińska ${ }^{149}$.

As can be seen, although the above unusual events made the nuns shelter strangers in their monasteries or change their place of residence, in fact, the time of natural disasters did not lead to any violation of the Rule or any change in the schedule of the day. The religious life of the nuns, living away from Poznan because of the plague, followed the usual pattern. The only novelties were each time different precautions to protect from contagion both the sisters and the priests who offered pastoral care to them. The situation was completely different during the wars, which forced a total disruption of monastic habits. While it is possible to find a fairly safe place where religious life can be lived without hindrance during a plague or a flood, it becomes impossible if foreign troops enter the country. Warfare instils constant anxiety and fear and necessitates frequent relocation. In this situation it is difficult to preserve a steady rhythm of the day. At that time even the administration of the sacraments becomes a problem, as witnessed in the section describing the life of nuns from Poznan in Silesia.

\section{Extraordinary Events, Disasters and Marching Armies in Greater Poland in the 17th and 18th Centuries and Their Impact on the Life of Nuns in the Benedictine Monastery as Reflected in the Monastic Chronicle Summary}

The Benedictine Monastery in Poznań was founded in 1607 by Magdalena Mortęska, the reformer of the religious order. By analysing the monastic chronicles, the author wanted to show the influence of extra-ordinary events in Greater Poland and Poznań in the 17th and 18 th centuries on the life of enclosed nuns. The article describes what changed when people visited the monastery, what life of nuns looked like during epidemics, floods and other disasters that took place in Greater Poland. The article moreover probes the influence of wars and the presence of foreign armies in the city of Poznań on the life of the Benedictine nuns.

Keywords: nuns in the Benedictine Monastery, Poznań, monastery, disasters, army

\footnotetext{
146 Ibidem, p. 209.

${ }^{147}$ Ibidem, p. 209.

148 J. Topolski, op. cit., pp. 123-124.

149 Franciszka Ponińska - abbess since 1712, d. 1735. See M. Borkowska, Leksykon zakonnic polskich epoki przedrozbiorowej, p. 89.
} 
About the Author: Ada Lewandowska - a graduate of Cardinal Stefan Wyszyński University, a Ph.D. student at the Institute of Historical Sciences of the Faculty of Historical and Social Sciences of this University. Her research interests include the history of the Church, mainly of enclosed orders of women religious. She is writing her doctoral dissertation under the supervision of Prof. Dr Hab. Jolanta M. Marszalska.

Translated by Marcin Turski 